\title{
Federal AND Alberta EnERgy Project REGULATION REFORM - AT WHAT COST EFFICIENCY?
}

\author{
ROWLAND J. HARRISON, Q.C., 'LARS OLTHAFER ${ }^{* *}$ \\ AND KATIE SLIPP ${ }^{* * *}$
}

Changes to regulatory regimes at the federal and provincial levels have recently transformed the way that energy resource projects will be considered and approved. The federal Canadian Environmental Assessment Act, 2012 and amended National Energy Board Act, along with the Alberta Responsible Energy Development Act, have taken decision-making power away from the regulators to government in an effort to align regulatory decisions with broader government policies. This article examines a number of the effects of the new regimes including the impact that the changes might have on the role of the regulator, the functioning of regulatory processes, and the development of Canada's natural resources.
Des changements aux régimes réglementaires aux niveaux fédéral et provinciaux viennent de modifier la manière de considérer et d'approuver les projets de ressources énergétiques. La Loi canadienne sur l'évaluation environnementale, 2012 fédérale et la Loi sur l'Office national de l'énergie amendée, ainsi que la Loi sur le développement énergétique responsable de l'Alberta marquent une transition du pouvoir décisionnel réglementaire, l'écartant des organismes de réglementation pour se rapprocher $d u$ gouvernement dans le but d'aligner les décisions réglementaires avec les plus grandes politiques $d u$ gouvernement. Cet article porte sur un nombre des répercussions des nouveaux régimes, incluant les conséquences de ces changements sur le rôle de l'organisme de réglementation, le fonctionnement des processus de réglementation et le développement des richesses naturelles du Canada.

\section{TABLE OF CONTENTS}

I. IntRODUCTION . . . . . . . . . . . . . . . . . . . . . . . . . . . . . 250

II. Federal Regulatory REForm . . . . . . . . . . . . . . . . . . . . 251

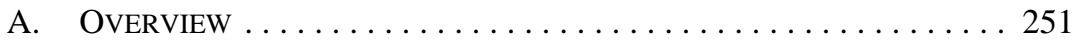

B. DRIVERS FOR CHANGE . . . . . . . . . . . . . . . . 252

C. Certificates of Public Convenience AND NeCESSity . . . . . . . 254

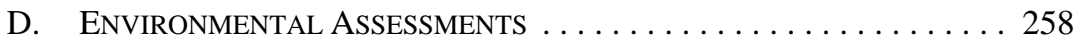

E. TIME LiMITS FOR DeCiSION-MAKING $\ldots \ldots \ldots \ldots \ldots \ldots \ldots 260$

F. Public Participation . . . . . . . . . . . . . . . . . . . . . . 264

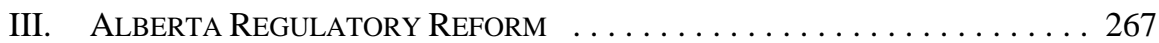

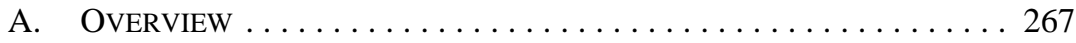

B. DRIVERS FOR CHANGE . ........................... 269

C. Policy Assurance Function . . . . . . . . . . . . . . . . . . . 269

D. TIME LiMITS For DeCision-MAKING $\ldots \ldots \ldots \ldots \ldots \ldots \ldots 271$

E. Public PARTICIPATION . . . . . . . . . . . . . . . . . . . . . . . . 273

F. Enforcement of Private Surface AgreEments . . . . . . . . 278

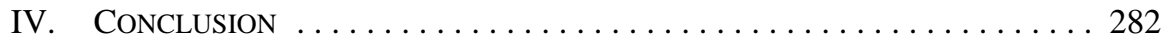

* TransCanada Chair in Administrative and Regulatory Law, University of Alberta.

*** $\quad$ Partner, Blake, Cassels \& Graydon LLP.

*** $\quad$ Associate, Blake, Cassels \& Graydon LLP. This article was current as to the time of writing, July 2013. Substantive changes to the energy regulatory regimes discussed are expected in the months after publication. 


\section{INTRODUCTION}

Recent legislative initiatives by the federal and Alberta governments are transforming the regulatory landscape for a significant cross-section of energy projects in Canada. At the federal level, the Canadian Environmental Assessment Act 2012 alters the triggers for environmental assessments, imposes streamlining measures, circumscribes public participation, and provides for the wider use of substituted provincial environmental assessment processes. ${ }^{1}$ Amendments to the National Energy Board Act have diminished the role of the National Energy Board (NEB or Board) in the approval process for federallyregulated major pipeline projects to making recommendations to federal cabinet following a review that is now subject to mandatory timelines and participation rights that are more limited than in the past. ${ }^{2}$

In Alberta, the Responsible Energy Development Act will, within the next year, combine the principal energy development regulatory functions of the Energy Resources Conservation Board (ERCB) and Alberta Environment and Sustainable Resource Development (ESRD) to create a single integrated regulator responsible for upstream oil and gas, oil sands, and coal development. ${ }^{3}$ The new Alberta Energy Regulator (Regulator) is required to exercise its functions in accordance with prescribed timelines and in close alignment with government policy, including regional land use plans which are focused on the management of cumulative effects of both operational and newly-proposed energy development projects.

These legislative developments reflect underlying changes in the political and legal landscape for major resource development projects. Proposals for federally-regulated major pipeline projects, such as the Mackenzie Gas Project, Northern Gateway, and Keystone XL, and provincially-regulated resource development, especially in the oil sands, engage an increasingly diverse range of interests among developers, governments, the public, First Nations, and environmental and other public interest groups. Accommodating and balancing these interests presents unprecedented challenges to the effective functioning of the regulatory process and ongoing investment in Canadian natural resources.

While the changes to the federal and provincial regimes are too numerous to address all within the scope of a single article, this article provides some examples of the impact that particular changes might have on the role of the regulator, the functioning of regulatory processes, and the development of Canada's natural resources. At one level, the changes may be seen as improvements to efficiency through integration, coordination, and other measures that will ultimately encourage investment. More broadly, however, the changes may reflect a movement towards limiting the role of the regulator in the overall review and decisionmaking process in an effort to align regulatory decisions with broader government policies.

SC 2012, c 19, s 52 [CEA Act 2012].

RSC, 1985, c N-7, as amended 6 July 2012 [NEB Act].

SA 2012, c R-17.3 [REDA]. Pursuant to Order in Council OC 163/2013, certain provisions of the REDA were proclaimed into force on 17 June 2013. 


\section{FEDERAL REGULATORY REFORM}

\section{A. OVERVIEW}

The legislation that resulted from the federal budget released on 29 March 2012 (2012 Budget) introduced fundamental changes to the role of the NEB in reviewing applications for certificates of public convenience and necessity (certificates) for interprovincial and international pipelines. ${ }^{4}$ The changes are both substantive and procedural. The NEB's redefined role is to make a recommendation which the Governor in Council (GIC) is free to accept or reject. ${ }^{5}$ Although the NEB will continue to issue certificates under section 52 of the NEB Act, it may now do so only at the direction of the GIC. Previously, the NEB itself decided whether to issue or deny a certificate; a decision by the NEB to issue a certificate required the approval of the GIC, whereas a decision to deny an application required no further approval. The NEB may now be directed by the GIC to issue a certificate notwithstanding that the NEB may have recommended that the certificate be denied. This is a fundamental, substantive change in the NEB's role that could have significant, lasting impacts on the NEB's processes, decisions, and status.

The enactment of the CEA Act 2012 has also redefined the NEB's role in the environmental assessment process for pipeline projects. Environmental assessments are now to be conducted by the NEB as part of a single, integrated process, rather than through a separate or joint panel review process administered by the Canadian Environmental Assessment Agency (CEA Agency). It is expected that this change will improve the efficiency of the review process, particularly by eliminating duplication and overlapping information and filing requirements.

On the procedural front, the recent amendments have imposed time limits on the NEB's review of applications for certificates. The NEB must submit its report to the GIC within a time limit specified in each case by the chairperson of the NEB, not to exceed 15 months from the date of the NEB's determination that it has a complete application. This change may result in improved predictability regarding the length of the NEB process but could prompt allegations of a denial of procedural fairness as previously understood in the context of the NEB's certificate process.

Finally, the NEB Act has been amended with a view to limiting participation in certificate proceedings. Previously, the NEB had a low threshold for granting intervenor status in its proceedings - a party only had to be an "interested person." The NEB also accepted all letters of comment. The amended NEB Act now requires the NEB to hear from parties who are, in the NEB's opinion, “directly affected” by the granting or refusing of an application and confers discretion on the NEB to consider the representations of any person who, in the NEB's opinion, has relevant information or expertise. ${ }^{6}$ It is expected that this change will substantially reduce the number of participants in future certificate proceedings, particularly

Jobs and Growth Act, 2012, SC 2012, с 31.

The Governor in Council is the Governor General, acting by, and with the advice and consent of, the Queen's Privy Council for Canada (i.e. the cabinet).

Supra note 2, s 55.2. 
when compared to the unprecedented levels of participation in the current Northern Gateway joint panel review process.

\section{B. DRIVERS FOR CHANGE}

Environmental impacts of pipeline projects have been considered by the NEB since the early 1970s as part of its overall public interest determination. When the original Canadian Environmental Assessment $A c t^{7}$ came into force in 1995, the NEB began conducting environmental assessments under that legislation. ${ }^{8}$ However, overlap and duplication between the requirements of the CEA Act, and the NEB's broad public interest mandate under the $N E B$ Act, including a consideration of environmental impacts, were immediately problematic. $^{9}$

The CEA Act provided for substitution where the Minister of Environment was satisfied that the substituted process would be equivalent to the CEA Act review process. ${ }^{10}$ It was widely assumed at the time of implementation of the CEA Act that this mechanism would be used for projects within the NEB's mandate. However, successive Ministers of Environment declined to approve substitution for projects coming before the NEB.

The original CEA Act also provided for environmental assessments to be conducted by joint review panels ${ }^{11}$ (JRP), and this procedure was adopted in 1995 for the Express Pipeline Project $^{12}$ as the first project to come before the NEB after the CEA Act had come into effect.

SC 1992, c 37, as repealed by CEA Act, 2012, supra note 1 [CEA Act].

8 See also, the decision of the Federal Court in Rocky Mountain Ecosystem Coalition v Canada (National Energy Board), (1999) FCJ no 1223 (QL), 174 FTR 17, where the NEB's consideration of a certificate application was handled by way of a comprehensive study report under the CEA Act. Notwithstanding the fact that the Department of Fisheries and Oceans (DFO) advised the NEB that it was not satisfied with the comprehensiveness of the draft comprehensive study report (as a result of outstanding information), the NEB issued the final comprehensive study report to the Minister of Environment for approval. The Minister concluded that the project was unlikely to have significant adverse effects, and the GIC approved the project. While the Court denied a request for mandamus directing DFO to engage in a panel review of the project, this illustrates one of the issues under the prior regime, which is the possibility of a CEA Agency review after the NEB has completed its hearing process.

$9 \quad$ While the history of federal environmental assessment is beyond the scope of this article, the earlier environmental assessment process was prescribed by the Environmental Assessment and Review Process Guidelines Order, PC 1984-2132 (1984) C Gaz 11, 2794 [EARPGO] The EARPGO was eventually replaced by the CEA Act in 1995, which has now been superseded by the CEA Act 2012. The changes to the federal environmental assessment regime effected by the CEA Act 2012 are, in significant part, the result of a recognition of the evolution of environmental assessment regimes both at the federal and provincial levels since the EARPGO, and the frequent duplication and undue regulatory burden that was endemic to those regimes. See the Supreme Court of Canada's decision in Quebec (Attorney General) $v$ Canada (National Energy Board), [1994] 1 SCR 159, for a detailed discussion of the application of the EARPGO in the context of an NEB decision regarding an application for licences to export electricity from Canada to the US.

10 CEAAct, supra note 7, s 43. Section 44 of CEA Act prevented the Minister from approving a substitution pursuant to section 43(1) unless the Minister was satisfied that (1) the process to be substituted would include a consideration of the factors required to be considered under subsections 16(1) and (2); (2) the public would be given an opportunity to participate in the assessment; (3) at the end of the assessment, a report would be submitted to the Minister; (4) the report would be published; and (5) any criteria established pursuant to section 58(1)(g) were met. Sections 16(1) and (2) referred to the factors that must be considered in a screening or comprehensive study of a project, as well as mediations or assessment by a review panel. Section 58(1)(g) provided the Minister with the authority to establish criteria for the appointment of mediators and members of review panels. CEA Act, ibid, s 40 .

Express Pipeline Project, NEB Report, OH-1-95 (May 1996). For another example of a JRP process for a NEB-regulated pipeline, see Georgia Strait Crossing Pipeline Ltd on behalf of GSX Canada Ltd Partnership, NEB Decision GH-4-2001 (November 2003). 
However, the JRP option still resulted in overlap, duplication, and inefficiencies, as the CEA Act process and the NEB process were not entirely compatible. As a result, in 2007, the CEA Agency and the NEB conducted a pilot substitution process for the review of the proposed Emera Brunswick Pipeline. ${ }^{13}$

Now, with the enactment of the CEA Act 2012, a single, integrated process has been implemented by designation of the NEB as the single agency responsible under the CEA Act 2012 for conducting environmental assessments of designated pipeline projects.

The immediate catalyst for most of the other recent changes to the NEB Act is likely found in the delays experienced in the regulatory reviews of the proposed Mackenzie Gas and Northern Gateway Projects. Somewhat uniquely, the NEB alone had direct regulatory authority with respect to all of the components of the Mackenzie Gas Pipeline Project (MGP) - from development and operation of the gas fields in the Mackenzie Delta to the interconnection of the MGP with the pipeline grid in Alberta. It might have been thought, therefore, that the NEB would present a single window into the regulatory process.

In fact, the regulatory authority of several other agencies was triggered, resulting in a Cooperation Plan for the Environmental Impact Assessment and Regulatory Review of a Northern Gas Pipeline Project through the Northwest Territories (Cooperation Plan). ${ }^{14}$ The Cooperation Plan identified, in addition to the NEB, seven other boards or agencies with mandatory hearing processes that would be triggered in reviewing the proposed project, as well as six agencies with a direct interest in environmental assessment and regulatory matters relating to the project.

Combined with the significant number of participants, the challenges in finding a path through this regulatory maze graphically illustrated the need to reduce overlapping and duplicative requirements. The Cooperation Plan provided for separate, although coordinated, reviews by a JRP and the NEB (through its regular certificate process) to conduct an environmental assessment review of the Project. An Agreement ${ }^{15}$ between the Mackenzie Valley Environmental Impact Review Board, the Inuvialuit, as represented by the Inuvialuit Game Council, and the Minister of Environment, established the JRP and set its terms of reference. The JRPA envisaged that the JRP, with seven members, would complete its review, including conducting community hearings throughout the North, in only ten months. ${ }^{16}$ The process in fact extended over nearly six years.

As widespread frustration with the MGP process mounted, it became apparent that the emerging Northern Gateway Project (Gateway) would, in many respects, present even greater

13 Emera Brunswick Pipeline Company Ltd, NEB Decision GH-1-2006 (May 2007).

14 Northern Pipeline Environmental Impact Assessment and Regulatory Chairs' Committee, Cooperation Plan for the Environmental Impact Assessment and Regulatory Review of a Northern Gas Pipeline Project through the Northwest Territories, online: National Energy Board Site <http://www.neb-one.gc. ca/clf-nsi/rthnb/pplctnsbfrthnb/mcknzgsprjct/cprtnpln-eng.pdf>.

15 The Mackenzie Valley Environment Impact Review of the Mackenzie Gas Project, the Inuvialuit, and the Minister of the Environment, Agreement for an Environmental Impact Review of the Mackenzie Gas Project, online: Mackenzie Valley Review Board <http://www.reviewboard.ca/upload/project_docu ment/EIR0405-001_Agreement_for_the_Environmental_Impact_Review_of_the_Mackenzie_Gas_ Project_1254158065.pdf $>$ [JRPA] . Ibid, s 4.6. 
challenges for the review process than the MGP. The review of Gateway is being conducted through a single JRP process under the NEB Act and the CEA Act by a panel of three members. ${ }^{17}$ The project raises a wide range of challenging issues; not surprisingly, unprecedented numbers of organizations and individuals are participating in the review process. It began to appear, particularly in light of the experience with the review of the MGP, that the Gateway process might well take even longer. Hence the introduction of time limits and restrictions on participation in future NEB certificate proceedings in the amendments to the NEB Act.

It also appears that Gateway may have been the immediate reason for the substantive change in the NEB's role from deciding to issue or deny a certificate to making a recommendation only, with the power to decide being vested in the GIC. Prior to the recent amendments, if the NEB were to deny the issuance of a certificate for Gateway (or any other project), the federal government would have had no means, other than legislation, to reverse that decision. The Minister did not refer directly to Gateway in his statement in speaking to this specific change in Parliament, but the timing does not appear to be coincidental:

We are also ensuring that there is clear accountability in the system. The federal cabinet will make the go, no-go decisions on all major pipeline projects, informed by the recommendations of the National Energy Board.

We believe that for major projects that could have a significant economic and environmental impact, the ultimate decision-making should rest with elected members who are accountable to the people rather than with unelected officials. Canadians will know who made the decision, why the decision was made and whom to hold accountable. ${ }^{18}$

This change also aligns the scope of NEB review more closely with the scope of review that has always been provided for under the CEA Act. ${ }^{19}$ In this regard the changes may also be considered to be a merging of the NEB and CEA Agency functions for major pipeline projects to align the processes for practical procedural reasons.

\section{Certificates of Public Convenience ANd Necessity}

Section 52 of the NEB Act, as recently amended, requires the NEB to submit to the Minister of Natural Resources a report setting out its recommendation and reasons as to whether or not a certificate should be issued for a proposed pipeline. The NEB is also required to include in its report terms and conditions to which a certificate would be subject regardless of its recommendation. ${ }^{20}$

The Minister of the Environment, Canada and the National Energy Board, Amendment to the Agreement Concerning the Joint Review of the Northern Gateway Pipeline Project, online: Northwest Coast Energy News and Issues <http://www.nwcoastenergynews.com/wp-content/uploads/2012/08/A2V5E4__Memorandum_-_Amendment_to_the_Agreement_concerning_the_joint_review_of_the_Northern_ Gateway_Pipeline_Project.pdf $>$.

House of Commons, Debates, 41st Parl, 1st Sess, No 115 (2 May 2012) at 7471.

That is, CEA Agency decisions have always been in the form of a recommendation to Cabinet. NEB Act, supra note 2, s 52(1)(b). 
The matters that the NEB may consider in making its recommendation are set out in section 52(2) of the NEB Act in terms that are mostly the same as the previous provision. These include the availability of supply, the existence of markets, the financing of the project, and "any public interest that in the NEB's opinion may be affected by the issuance of the certificate or the dismissal of the application." ${ }^{21}$ Thus, on first reading, it appears that the NEB's broad public interest mandate has been maintained.

However, the amended subsection has introduced a limitation that may be significant in enabling the NEB to circumscribe the matters that it will consider. Previously, the NEB was directed by section 52(1) to have regard to "all considerations that appear to it to be relevant." 22 The revised mandate in section 52(2) is to have regard to "all considerations that appear to it to be directly related to the pipeline and to be relevant." ${ }^{3}$ While the determination of what is "directly related" is a matter for the NEB, the limitation will provide the NEB with the means to narrow the issues it will consider, perhaps by rejecting, for example, arguments that it should consider developments upstream and downstream from a proposed pipeline. Presumably, this was the intention of the federal government, in keeping with the overall direction of the amendments towards limiting the scope of NEB certificate proceedings.

After the NEB's report has been submitted to the Minister, the GIC may, by order, refer the recommendation or any of the terms and conditions back to the NEB for reconsideration. ${ }^{24}$ The GIC order, which is binding on the NEB, may direct the NEB to take into account, in conducting its reconsideration, "any factor specified in the order." 25

In reporting on its reconsideration, the NEB shall "either confirm its recommendation or set out a different recommendation." ${ }^{26}$ Where a term or condition is referred back, the NEB shall confirm the term or condition, state that it no longer supports that term or condition or replace that term or condition with another. ${ }^{27}$ As with its original report, where the NEB's recommendation after reconsideration is to deny an application, it shall nevertheless set out "all the terms and conditions that it considers necessary or desirable in the public interest, to which the certificate would be subject if the GIC directs the NEB to issue a certificate.”28 The GIC may refer a reconsideration report back to the NEB for further reconsideration, with the NEB being required to report again. ${ }^{29}$

After receiving the NEB's report, the GIC may, by order, “direct the [NEB] to issue a certificate in respect of the pipeline or any part of it," notwithstanding that the NEB's recommendation, in either its original report or its reconsideration report, may have been that the application should be dismissed. ${ }^{30}$ Alternatively, the GIC may direct the NEB to dismiss

Ibid.

This phrase appeared in the original enactment of the NEB Act in 1959 (SC 1959, c 46, s 44).

NEB Act, supra note 2 [emphasis added].

Ibid, s 53(1).

Ibid, s 53(2).

Ibid, s 53(6)(a).

Ibid.

Ibid, s 53(7).

Ibid, s 53(9).

Ibid, s 54(1)(a). 
the application, again regardless of the NEB's recommendation. ${ }^{31}$ In either event, the GIC order must set out the reasons for the order. ${ }^{32}$

While it is the GIC that makes the ultimate decision with respect to certificates, the terms and conditions of a certificate are those determined by the NEB. Section 54(1)(a) states that a direction to the NEB to issue a certificate shall "make the certificate subject to the terms and conditions set out in the [NEB] report."33

The chairperson of the NEB has been quoted in the press as saying that these changes (and the mandated time limits discussed below) will not "change at all the way we work."34 However, in view of the fundamental change in the NEB's substantive role, it is difficult to see how there will not be both direct and, potentially, indirect effects.

The reconsideration procedure immediately raises the question of what process the NEB will adopt before submitting its reconsideration report to the GIC. The status of the NEB as a court of record ${ }^{35}$ has not been changed by the amendments, nor has the requirement under section 24(1) that hearings before the NEB with respect to the issuance, revocation or suspension of certificates be public. Section 24(1) does not explicitly state that the NEB shall conduct hearings on certificate applications. However, the express exception in section 24(2) that hearings need not be held in certain circumstances implies that public hearings are generally required for such applications. The NEB's consistent practice has been to hold public hearings on section 52 certificate applications. Furthermore, section 53(2) of the amended NEB Act states that any GIC order to the NEB to reconsider its report may direct the NEB "to conduct the reconsideration" taking into account any factor specified in the order. ${ }^{36}$ It can be argued that this phrasing contemplates something more than a process that is exclusively internal to the NEB.

It should also be noted that it has been the NEB's practice, based on judicial guidance, ${ }^{37}$ to circulate draft proposed certificate conditions to the parties to a proceeding for comment. The reasons for the practice would seem to be equally applicable to any proposed change in a term or condition that might be contemplated as part of a reconsideration by the NEB as directed by the GIC.

It may be argued, therefore, that procedural fairness would require that there be $a$ process for reconsideration by the NEB, beyond a mere internal review by the NEB itself, before it submitted a further report to the GIC. It does not follow, however, that such a process need be similar in its structure to the process followed by the NEB in its original consideration of a certificate application. While many of the hallmarks of the NEB's formal status as a quasi-

Ibid, s 54(1)(b).

Ibid, s 54(2).

Ibid, s 54(1)(a).

Nathan Vanderklippe, “The NEB’s Gaétan Caron: Strumming a new kind of power chord,” The Globe and Mail (23 March 2013) B3.

NEB Act, supra note 2, s 11(1).

Ibid.

Flamborough v National Energy Board, Interprovincial Pipe Line Ltd and Canada, 198455 NR 95 (FCA). 
judicial, decision-making authority are still found in the NEB Act, ${ }^{38}$ the NEB's function as distinct from its formal status - is no longer as a decision-maker with respect to certificates.

The distinction between quasi-judicial and administrative functions has been less significant in Canadian administrative law since the decision of the Supreme Court of Canada in Nicholson v. Haldimand-Norfolk Regional Board of Commissioners of Police. ${ }^{39}$ However, the nature of the specific function in issue is relevant in determining the content or level of procedural fairness that is appropriate in a particular case. ${ }^{40}$ Any procedure that may have been required of the NEB as a decision-maker would not necessarily be required of it as the maker of a recommendation. Furthermore, the NEB's specific function in the context of the reconsideration process under the amended Act is narrower than its function in formulating its original report under the amended section 52. It can be argued that the NEB's role in reconsidering its report at the direction of the GIC calls for a procedure that is appropriate to the Board's specific responsibility in reconsidering a recommendation at the direction of the GIC and that such a procedure need not be as comprehensive and structured as might be expected of the NEB in its initial consideration of certificate applications.

Apart from these questions that arise directly from the change in the NEB's role with respect to certificate applications, other changes in the status, and perhaps procedures, of the NEB could emerge over time. The vesting of direct decision-making authority in the GIC could result in the NEB's role being perceived as being less important than was the case in the past. At the very least, it distinguishes the NEB's former role as a public-interest decision maker in the certificate process from its current role under the revised NEB Act.

Of more immediate concern, however, is the potential for erosion of the reputation that the NEB has enjoyed for independence. The reconsideration process requires interaction between the GIC and the NEB. While that interaction might be transparent, it raises a risk that the cabinet could attempt to use the NEB to support its own decisions. It should be recalled here that the NEB may be directed by the GIC "to conduct its reconsideration taking into account any factor specified in the [GIC] order. ${ }^{{ }^{41}}$ Furthermore, the NEB may well feel pressure to make a particular recommendation if confronted with indications of the GIC's likely final decision.

Clearly, in respect of the certificate process, the NEB is not as independent of government under the amended scheme as it was previously. As is discussed in a later section, this concern is exacerbated by the imposition of time limits on both the NEB's certificate proceedings and its reconsideration process at the direction of the GIC.

Finally, it must be noted that the recent amendments expressly exclude NEB reports under the amended section 52 from the NEB Act's provisions for appeals to the Federal Court of Appeal. Like the prior provision, section 22 of the NEB Act provides for an appeal, with superior court of record and, under section 24(1), its certificate hearings must be public. [1979] 1 SCR 311.

See e.g. Baker v Canada (Minister of Citizenship and Immigration), [1999] 2 SCR 817. NEB Act, supra note 2, s 53(2). 
leave, to the Federal Court of Appeal from “a decision or order of the Board.” Section 22(4), however, provides that no report submitted under sections 52 or 53, and no part of any such report, "is a decision or order of the Board" for the purposes of an appeal.

At the same time, the amended Act recognizes the possibility of judicial review of a GIC order directing the NEB to issue a certificate or to dismiss an application. Section 55 provides that judicial review by the Federal Court of Appeal is commenced by making an application for leave to the Court, which must be made within 15 days after the publication of the order in the Canada Gazette. ${ }^{42}$

\section{EnVironmental Assessments}

The NEB's public interest mandate under section 52 of the NEB Act is broad enough to include consideration of the environmental impacts of proposed pipeline projects. The NEB has explicitly considered environmental matters in its decisions since the early 1970s. Since 1995, it has also conducted environmental assessments under the CEA Act. The overlap and duplication resulting from compliance with the requirements of two regimes are discussed above in considering the factors leading to changes in both.

Under the CEA Act 2012, the NEB is now the sole responsible authority for a designated project that includes activities regulated under the NEB Act (or the Canada Oil and Gas Operations $A c t)^{43}$ and that are linked to the NEB as specified in the regulations or a designation made by the Minister of Environment. ${ }^{44}$ The result is that, where the CEA Act 2012 requires an environmental assessment of any project within the NEB's jurisdiction, the assessment will be conducted by the NEB as part of its single review process. ${ }^{45}$

The designation of the NEB as a responsible authority under the CEA Act 2012 does not simply replace the requirements of the CEA Act with the NEB's public interest mandate to review environmental matters. The CEA Act 2012 requirements must still be satisfied, however, where an environmental assessment for a NEB-regulated project is required, that assessment will now be carried out by the NEB. The NEB's report on the environmental assessment is to be submitted to the Minister at the same time as the NEB's report on the

Ibid. The NEB Act does not contemplate the possibility of judicial review of the NEB's recommendation or process that resulted in a report under sections 52 or 53 . There is, however, the possibility of an application to the Board to review or vary the underlying recommendation or process under section 21 of the NEB Act. While section 22(4) regarding appeals provides that "no report submitted by the Board under section 52 or $53 \ldots$ and no part of any such report, is a decision or order of the Board," that limitation is for the purpose of that section (section 22) only. Section 21 contains no such limitation.

43 RSC 1985, c O-7 [COGOA].

44 CEA Act 2012, supra note 1, s 15(b). Note that the federal government has recently released draft regulations entitled Regulations Amending the Regulations Designating Physical Activities, (2013) C Gaz I, 825, which are intended to, among other things, more closely align designated projects with NEB jurisdiction under the NEB Act by requiring environmental assessment for NEB-regulated pipelines that are $40 \mathrm{~km}$ or more, regardless of whether or not they are on a new right of way.

45 The changes to the federal environmental assessment regime effected under the CEA Act 2012 are intended to streamline the environmental assessment process for various physical activities designated under that regime. While the construction, operation, decommissioning, and abandonment of NEBregulated oil and gas pipelines longer than $75 \mathrm{~km}$ on a new right of way is one type of such physical activity (Regulations Designating Physical Activities, SOR/2012-147, s 38(a)), those are likely to make up only a small number of the activities that trigger federal environmental assessment. The majority of activities that will be caught by the CEA Act 2012 are likely to be provincially-regulated energy projects that are designated by regulation as requiring a federal environmental assessment. 
application for a certificate under the NEB Act. ${ }^{46}$ Section 30 of the CEA Act 2012 sets out a process, in terms similar to the reconsideration process under the NEB Act discussed above, for the GIC to order the NEB to reconsider any of the NEB's recommendations in its environmental assessment report.

The CEA Act 2012 requires the GIC to decide, taking into account the implementation of mitigation measures, that the project:

(i) is not likely to cause significant adverse environmental effects,

(ii) is likely to cause significant adverse environmental effects that can be justified in the circumstances, or

(iii) is likely to cause significant adverse environmental effects that cannot be justified in the circumstances. ${ }^{47}$

The GIC decision under this requirement of the CEA Act 2012 is directly linked to the GIC's authority under the NEB Act with respect to the issuance or denial of a certificate by requiring that the GIC decision, with respect to the environmental assessment, be made by the same order as is issued under section 54 of the NEB Act. ${ }^{48}$

The integrated process under the CEA Act 2012 does not extend to projects within the NEB's jurisdiction in the North, under either the NEB Act or the COGOA. Environmental assessments of such projects may still be required under the Mackenzie Valley Resource Management Act, ${ }^{49}$ the Inuvialuit Final Agreement, ${ }^{50}$ or the Nunavut Land Claims Agreement. ${ }^{51}$ Furthermore, where an environmental assessment of a NEB-regulated project is not required by the CEA Act 2012 or by any of these acts, the NEB will continue to conduct assessments as part of its broad public interest mandate under the NEB Act.

The CEA Act 2012 requires a responsible authority (which by definition includes the NEB) to establish a participant funding program "to facilitate the participation of the public in the environmental assessment of any designated project."52 The NEB has established a Participant Funding Program to provide financial assistance "to support the timely and meaningful engagement of individuals, Aboriginal groups, landowners, incorporated nonindustry not-for-profit organizations, or other interest groups." ${ }^{53}$ Funding is only available to parties who are granted intervenor status in accordance with the NEB's guidance on participation, which is discussed below.

CEA Act 2012, supra note 1, s 29(2).

Ibid, ss 31(1)(a)(i-iii).

Ibid, s 29(2).

SC 1998, с 25.

Western Arctic (Inuvialuit) Claims Settlement Act, SC 1984, с 24.

Nunavut Land Claims Agreement Act, SC 1993, c 29.

CEA Act 2012, supra note 1, s 58.

National Energy Board, "Participant Funding Program,” online: National Energy Board Site <http:// www.neb-one.gc.ca/clf-nsi/rthnb/pblcprtcptn/prtcpntfndngprgrm/prtcpntfndngprgrm/llctnfnd_nbrdgln9 rvrslphs1-eng.pdf>; National Energy Board, Guide to the National Energy Board Participant Funding Program Under the National Energy Board Act, online: National Energy Board Site <http://www.nebone.gc.ca/clf-nis/rthnb/pbc1prtcptn/prtcpntfndngprgrm/prgrm/prgrmgd-eng.pdf> 


\section{E. TIME LIMITS FOR DECISION-MAKING}

The NEB's certificate report under section 52 of the NEB Act must be submitted within the time limit specified by the chairperson of the NEB, which must be no longer than 15 months after the NEB is satisfied that it has a complete application. ${ }^{54}$

Once triggered, the time limit can, with the chairperson's approval, be extended if the NEB requires the applicant to provide further information or undertake any study with respect to the pipeline. ${ }^{55}$ Any amount of time taken by the applicant to comply is excluded from the time limit. Further, the Minister may extend a time limit by up to three months and the GIC may, on the recommendation of the Minister, "further extend the time limit by any additional period." ${ }^{\text {}}$ The Minister can issue a binding directive requiring the chairperson to specify a time limit determined by the Minister. ${ }^{57}$

The amendments also impose a time limit on GIC decision-making following the submission of the NEB's recommendation report. As previously discussed, under the revised scheme, it is the GIC that makes the final order directing the NEB to either issue a certificate or to dismiss an application. ${ }^{58}$ Section $54(3)$ provides that this "order must be made within three months after the [NEB's] report is submitted to the Minister.” The GIC may, however, extend that time limit for "any additional period or periods of time." 59 Thus, the GIC itself has the authority to extend the time limit to which it would otherwise be subject.

A failure to comply with the time limits does not affect the NEB's jurisdiction or its obligation to submit its report to the Minister. Anything done in relation to the relevant application remains valid, ${ }^{60}$ and the GIC may make an order directing the NEB to issue a certificate or dismiss an application for a certificate notwithstanding that the applicable time limit has expired. ${ }^{61}$

However, while a failure to meet a time limit does not have any substantive effect on the processing of certificate applications, the scheme includes several mechanisms to ensure adherence to time limits. The chairperson is given general authority to issue directives to NEB panels to ensure that applications are dealt with in a timely manner, ${ }^{62}$ as well as specific authority to take any measure considered "appropriate to ensure that a time limit is met."63 Measures may include removing any or all members of a panel, authorizing one or more members to deal with the application, and increasing or decreasing the number of members dealing with the application. ${ }^{64}$ It is expressly provided that these measures may include the

NEB Act, supra note 2, s 52(4).

Ibid, s 52(5).

Ibid, s 52(7).

Ibid, s 52(8).

Ibid, s 54(1).

Ibid, s 54(3).

Ibid, s 55.1.

Ibid, s 55.1(2).

Ibid, s 6(2.1).

Ibid, s 6(2.2).

Ibid, ss 6(2.1)-(2.2). 
designation of "a single member, including the Chairperson, as the sole member ... authorized to deal with the application.”65

In most regulatory proceedings, the fundamental principle that "he who hears must decide" would generally require that, where a panel is reconstituted, the matter be reheard. Section 6(2.4) expressly rejects this usual consequence:

If the composition of the panel dealing with an application is changed as a result of any measure taken under subsection (2.2),

(a) evidence and representations received by the Board in relation to the application before the taking of the measure are considered to have been received after the taking of the measure; and

(b) the Board is bound by every decision made by the Board in relation to the application before the taking of the measure unless the Board elects to review, vary or rescind it. ${ }^{66}$

Together, these provisions could be applied to replace an entire panel with a single member who, under section 6(2.4), would be deemed to have heard all evidence and representations received prior to the designation of that single member. The principle "he who hears must decide" may now be "he who has not heard is deemed to have heard."

The possibility that a panel could be replaced by a single member to complete a hearing ${ }^{67}$ also appears to conflict with the requirement that a quorum of the NEB is three members. ${ }^{68}$ In discussing this issue, it should be noted that there are two other provisions of the NEB Act that explicitly allow the chairperson to appoint a single member to perform certain functions. The first of these is section 14(1), which expressly excludes the duties and functions of the NEB under, inter alia, section 52, from the functions that can be assigned to a single member. ${ }^{69}$ The chairperson's power to appoint a single member under section $6(2.2)$ to continue a hearing under section 52, appears to be inconsistent with the intention behind this limitation in section 14(1), as well as conflicting directly with the general quorum provision. $^{70}$

The second such provision is section 15, under which the chairperson may authorize one or more members to report to the NEB on certain matters. ${ }^{71}$ Significantly, however, section 15(1.1) expressly provides that where three members are so authorized to report to the NEB, those members do not constitute a quorum of the NEB. Again, the application of section 6(2.2) to appoint a single member would be inconsistent with the limitation found in section 15(1.1) on exceptions to the general quorum requirement of three members.

Several other elements of the time limit scheme directly challenge the principles of procedural fairness by circumscribing the extent to which panels are masters of their own

Ibid, s 6(2.3).

Ibid.

Ibid, s 6(2.3)

Ibid, s $7(2)$.

Ibid.

Ibid.

Ibid. 
procedure. Panels are now subject to the possibility of directives with respect to the manner in which they are to deal with an application and other specific measures that the chairperson may take to ensure that a time limit is met. $^{72}$

As noted, these include removal of any or all members of a panel. The NEB Act includes a number of provisions to support the independence of NEB members by ensuring their security of tenure as NEB members. However, while tenure as a NEB member may be secure, NEB members are now subject to the possibility of being removed from a panel during the course of a hearing by the chairperson, possibly acting at the direction of the Minister. Security of tenure as a member of the NEB may provide little assurance of independence for members who face the possibility of removal from a panel based on the subjective judgment of the chairperson or the Minister.

In addition to these direct impacts on the independence of NEB panels, the time limits scheme is likely to have other less obvious effects on the independence of panels and, indeed, on the efficacy of the NEB's processes for considering certificate applications. These can be discussed under two headings: firstly, the "quality" of panel decisions, and secondly, the changed nature of the relationship between the chairperson and other NEB members.

Time limits may constrain panels from compiling complete records and restrict participants in fully presenting their views. Such limits may also constrain panels in reaching their conclusions and, most importantly, in providing reasons to support those conclusions. ${ }^{73}$

A second area of concern is that the chairperson may now intervene directly in the processes of individual panels. Prior to the amendments, the chairman ${ }^{74}$ of the NEB was the chief executive officer of the NEB, and had "supervision over and direction of the work" and staff of the NEB. ${ }^{75}$ The chairman otherwise had no special status vis-à-vis other members of the NEB and was regarded as "a first among equals." Once a panel was designated by the NEB to deal with an application, that panel fulfilled its mandate independently of any direction by the chairman.

Under the $N E B$ Act as amended, the chairperson is now empowered to intervene directly in a panel process to take any measure considered appropriate to ensure that a time limit is met, including the removal of panel members. The chairperson is no longer "first among equals.” Individual panel members may now be influenced by their knowledge that by following a particular procedural course - a course that they believe would best uphold the

$72 \quad$ Ibid, ss 6(2.1)-(2.2).

73 It is interesting to note here the report in early 2013 that the Alberta government had rejected a request from Justice Vertes, the head of the commission of inquiry into queue-jumping in the Alberta health system, for a six-month extension to his Commission's deadline of 30 April 2013. Justice Vertes was quoted in press reports as saying: "Not only is such a rejection unprecedented, it borders on an interference with the independence of the Commission, since it would require me to rush through a report that would not be as complete or thorough as I would want" ("Queue-jumping inquiry Commissioner Vertes blasts Reford-government for potential interference,” Calgary Herald (28 February 2013), online: Calgary Herald <http://www.blogs.calgaryherald.com/2013/02/28/queue-jump ing-inquiry-commissioner-vertes-criticizes-redford-governments-potential-interference/>). If held to the April 30 deadline, he would have to file an "incomplete" report. The government subsequently relented and granted the extension requested.

74 "Chairman" was changed to "Chairperson" in the recent amendments to the Act.

NEB Act, supra note 2, s 6(2). 
integrity of the process and enable them to come to their best conclusion — they could risk being removed from a panel. This could place them in a conflict of interest, and they could be perceived as undermining the integrity of the process and the quality of its outcomes.

Mandatory time limits may result in shorter regulatory processes and, in that respect, may be regarded as improving the "efficiency" of those processes. However, in the case of the time limits scheme under the NEB Act, there is a risk of allegations that efficiency comes at the expense of an assault on principles of procedural fairness. It may also be argued that this could lead to a diminution in the quality of the outcomes of those processes, resulting from limits on the ability of panels to compile complete records or provide fully developed supporting reasons for their conclusions.

In light of the direct rejection of principles of procedural fairness that characterize the time limits scheme, inevitably it will be asked whether there may be grounds for challenging any of these provisions. In addressing this question, first it must be noted that the Act expresses a clear intent that time limits should prevail over considerations of fairness. Section 11(4) provides:

Subject to subsections 6(2.1) and (2.2), all applications and proceedings before the Board are to be dealt with as expeditiously as the circumstances and considerations of fairness permit, but, in any case, within the time limits provided for under this Act. ${ }^{76}$

The Supreme Court of Canada was clear in Ocean Port Hotel Ltd. v. British Columbia ${ }^{77}$ that, absent constitutional challenge, a statutory regime prevails over common law principles of natural justice, including principles of independence. In a unanimous decision, the Court was unequivocal in its view that the degree of independence required of tribunal members may be ousted by express statutory language or necessary implication:

Ultimately, it is Parliament or the legislature that determines the nature of a tribunal's relationship to the executive. It is not open to a court to apply a common law rule in the face of clear statutory direction. Courts engaged in judicial review of administrative decisions must defer to the legislator's intention in assessing the degree of independence required of the tribunal in question.

[G]iven their primary policy-making function, it is properly the role and responsibility of Parliament and the legislatures to determine the composition and structure required by a tribunal to discharge the responsibilities bestowed upon it. While tribunals may sometimes attract Charter requirements of independence, as a general rule they do not. Thus, the degree of independence required of a particular tribunal is a matter of discerning the intention of Parliament or the legislature and, absent constitutional constraints, this choice must be respected. $^{78}$ 
While the Court was speaking specifically of the independence of tribunals, the principle would appear to apply equally to respecting legislative intent with respect to tribunal procedure - restrictions on tribunal procedure could be argued to be an aspect of interfering with tribunal independence. ${ }^{79}$

From a broader perspective, the legitimacy of any particular regulatory agency ultimately rests on respect for the agency's perceived de facto independence, the rigor of its processes, and its integrity. There is little doubt that the time limits scheme imposed on the NEB by the recent amendments to the NEB Act undermines the previous foundation for the NEB being perceived as truly independent and the master of its own procedure. The NEB will, therefore, be challenged to respond in ways that are particularly alert to the risk that the reputation of, and respect for, independence and integrity the NEB has largely enjoyed to date, could be jeopardized.

Finally, it is interesting to note that the lengthy review of the MGP by the JRP, which appears to have been the catalyst leading to the imposition of time limits, was not a NEB process. The NEB conducted its own process under the NEB Act and was not responsible for the length of the overall process. Nevertheless, it is the NEB that has been subjected to time limits for future proceedings. It is also interesting to note that the NEB, for many years, has had its own performance standards for the timely processing of all applications to the NEB. ${ }^{80}$ It should be asked, therefore, whether some form of guidelines, as distinct from mandatory limits, might have been a more proportional response to concerns about the length of the regulatory review process, particularly in light of the denial of procedural fairness that the latter entails.

\section{F. Public Participation}

Section 55.2 of the amended NEB Act provides:

On an application for a certificate, the Board shall consider the representations of any person who, in the Board's opinion, is directly affected by the granting or refusing of the application, and it may consider the representations of any person who, in its opinion, has relevant information or expertise. A decision by the Board as to whether it will consider the representations of any person is conclusive. ${ }^{81}$

Furthermore, it is unlikely that any of the protections guaranteed by the Canadian Charter of Rights and Freedoms, Part I of the Constitution Act, 1982, being Schedule B to the Canada Act 1982 (UK), 1982, c 11, or the Canadian Bill of Rights, SC 1960, c 44, reprinted in RSC 1985, App III, would be engaged in the context of the Board's revised role as the maker of recommendations.

80 See National Energy Board, "NEB service standards," online: National Energy Board Site <http:// www.neb-one.gc.ca/clf-nsi/rpblctn/rprt/dprtmntlprfrmncrprt/2011-2012/srvcstndrd2011-2012-eng.html> . For non-hearing applications, the service standard is 80 percent of decisions released within 40 calendar days for issues of minor complexity (maximum time limit of 130 days); 80 percent of decisions released within 90 calendar days for issues of moderate complexity (maximum time limit of 210 days); and 80 percent of decisions released within 120 calendar days issues of major complexity (maximum time limit of 300 days). For 2012 results see National Energy Board, Annual Report 2012 to Parliament, online National Energy Board Site < http://www.neb-one.gc.ca/clf-nsi/rpblctn/rprt/nnlrprt/2012/nnlrprt2012.eng.html>. 
Previously, the NEB generally set a low threshold for granting intervenor status in facilities proceedings and accepted letters of comment without restriction. ${ }^{82}$ However, the unprecedented number of participants in the Gateway JRP proceeding (and, in the view of some, the questionable link of many of those participants to the issues before the JRP) clearly demonstrated the need for structure and restrictions in respect of rights of participation.

Corresponding provisions to section 55.2 of the NEB Act are found in the CEA Act 2012, dealing specifically with participation by interested parties in the environmental assessment of a designated project for which the NEB is the responsible authority. Section 28 of the CEA Act 2012 provides that the NEB must ensure that any "interested party" is provided with an opportunity to participate in the environmental assessment of the project. ${ }^{83}$ For these purposes, under section 2(2) of the CEA Act 2012, an "interested party" is a person who, in the NEB's opinion, is directly affected by the carrying out of the project or is a person who has relevant information or expertise.

No doubt the practice of the NEB in applying section 55.2 will evolve, and may be shaped as a result of challenges to the NEB and to the courts. ${ }^{84}$ The NEB has, however, issued general guidance under the title “Applying to Participate in a Hearing," dated 22 March 2013. ${ }^{85}$ The guidance states that the changes to the Act "are intended to promote fairness and efficiency by ensuring NEB hearings can take place in a timely manner." ${ }^{86}$ It states that the NEB will decide who may be directly affected "on a case-by-case basis." The NEB may consider whether a person's interest is "specific and detailed ... rather than a general public interest," giving as examples:

- $\quad$ commercial, property or other financial interest (including employment);

- $\quad$ personal use and occupancy of land and resources; or

- $\quad$ use of land and resources for traditional Aboriginal purposes. ${ }^{87}$

In considering whether there may be a direct effect on a person's interest, the guidance states that the NEB may consider:

- $\quad$ The degree of connection between the project and the interest.

- $\quad$ The likelihood and severity of harm a person is exposed to.

The test under the prior regime was that an intervenor had to be an "interested person." While this language is still included in the National Energy Board Rules of Practice and Procedure, 1995, SOR/95208, s 28, this test is presumably overridden by the changes to the NEB Act, ibid, s 55.2.

83 Supra note 1.

84 See the discussion below for an overview of how the "directly and adversely affected" test for standing has been interpreted under the provincial regime.

85 National Energy Board, “Applying to Participate in a Hearing,” online: National Energy Board Site <http://www.neb-one.gc.ca/clf-nsi/rthnb/pblcprtcptn/pblchrng/pblchrng-eng.html>. The Board has also issued guidance for participation in other hearings, stating that the Board will allow a person to participate if that person's interest is “sufficiently impacted” by the Board's decision and may allow a person to participate if the person's participation "will assist the Board in making its decision” (ibid).

Ibid.

Ibid. 
- $\quad$ The frequency and duration of a person's use of the area near the project. ${ }^{88}$

In choosing to hear from any person who, in the NEB's opinion, has relevant information, the NEB may consider:

- $\quad$ the source of the person's knowledge (for example, local, regional or Aboriginal);

- the extent to which the information is within the project scope and related to the list of issues; and

- $\quad$ how much value the information will add to the Board's decision or recommendation. ${ }^{89}$

In deciding whether a person has relevant expertise, the NEB may consider:

- $\quad$ the person's qualifications (for example, the person has specialist knowledge and experience);

- the extent to which the person's expertise is within the project scope and related to the list of issues; and

- $\quad$ how much value the information will add to the Board's decision or recommendation. ${ }^{90}$

The guidance also notes that the Application to Participate form will likely be unique for each hearing. The NEB will advise who is allowed to participate "and by what method of participation."91

The first Application to Participate Form was issued by the NEB on 5 April 2013 in proceeding $\mathrm{OH}-002-2013$ to consider an application by Enbridge Pipelines Inc. for its Line 9B Reversal and Line 9 Capacity Expansion Project. ${ }^{92}$ The application form runs nine pages. It identifies three methods or levels of participation:

- $\quad$ Commenters participate by submitting a Letter of Comment with the Board. Writing a Letter of Comment allows you to share your views on the Application in a letter. Commenters do not ask questions about other Participants' evidence or make a final argument at the oral portion of the hearing. This option is not eligible for the NEB’s Participant Funding Program.

- Being an Intervenor requires a time commitment to the hearing process. Intervenors are obligated to respond to information requests on any evidence they file. Further, Intervenors may ask information requests of other participants who filed evidence, file evidence themselves, and present final argument. They may also apply for and be granted funding through the NEB's Participant Funding Program.

Ibid.

Ibid.

Ibid.

Ibid.

Enbridge Pipelines Inc, “Application to Participate Form,” online: National Energy Board Site <http:// www.neb-one.gc.ca/11-eng/livelink.exe/fetch/2000/90464/90552/92263/790736/890819/918701/ 941089/A5-3_-_Application_Form_to_Participate_in_a_Hearing_-_A3G6L3_.pdf?nodeid=941615\& vernum $=0$. 
- Government Participants have participation rights similar to Intervenors, but may not be subject to answering questions from other Participants. They are not eligible for funding. This participation option is only available to government departments and agencies. ${ }^{93}$

Based on the NEB's general guidance for participation in hearings and this hearingspecific application form, it is seems clear that participation in future NEB certificate proceedings will not be as broad as in the past, and certainly not at the levels being experienced in the Gateway proceedings. ${ }^{94}$

\section{Alberta Regulatory Reform}

\section{A. OVERVIEW}

Following suit with changes at the federal level, the Alberta government has recently passed legislation to establish a "one stop” regulatory process for upstream energy resource development in the province. ${ }^{95}$ However, whereas the details of the federal process are welladvanced, key aspects of the provincial regime will be determined by rules and regulations, some of which are still pending. In the interim, it appears that ERCB legislation, regulations, directives, and other guidance will continue to remain in force unless otherwise ordered. ${ }^{96}$

The REDA establishes an integrated regime for the upstream development of oil, gas, oil sands, and coal by combining the functions of the ERCB, ${ }^{97}$ energy resource functions of ESRD (with respect to the environment and public lands oversight) and mineral exploration functions of the Alberta Department of Energy ${ }^{98}$ into a single Regulator. ${ }^{99}$ The mandate of the Regulator is to "provide for the efficient, safe, orderly and environmentally responsible development of energy resources in Alberta," ${ }^{100}$ which the Regulator will effect under its

Ibid at 8.

By letter dated 22 May 2013, the NEB advised that it had received 177 applications to participate in the Enbridge Line 9B Reversal and Line 9 Capacity Expansion Project proceeding. Of these, 158 were granted as requested, 11 were instead granted the opportunity to submit a letter of comment, and eight were not granted standing. Sheri Young (Secretary for the Board), Hearing Order RHW-001-2012 (22 May 2013), online: NEB <https://www.neb-one.gc.ca/ll-eng/livelink.exe/fetch/2000/90465/92837/283 788/811583/956588/956602/A3H8I5_-_Letter_Decision_-_RHW-001-2012__Centra_Transmission_ Holdings_Inc._Transportation_Tariff_and_Tolls_for_2012? nodeid=956377 \& $\overline{\text { vernum }}=0$ > .

See $R E D \bar{A}$, supra note 3.

See e.g. ibid, s 82, which provides that reference to the "Energy Resources Conservation Board” in "any enactment, approval, order, direction, or declaration, or in any contract, agreement or other instrument in force in Alberta," is deemed to be a reference to the "Regulator." See also the Miscellaneous Corrections (Alberta Energy Regulator) Regulation, Alta Reg 89/2013, which provides that, among others, the Oil and Gas Conservation Regulations, Alta Reg 151/71; the Coal Conservation Regulation, Alta Reg 270/81, the Pipeline Regulation, Alta Reg 91/2005; and the Oil Sands Conservation, Regulation, Alta Reg 76/88, are amended, principally to replace "regulation" with "rule" and "Board" with "Regulator."

The ERCB was dissolved on proclamation of the REDA (REDA, ibid, s 81).

This article will focus on changes to the ERCB and ESRD regimes governing energy resource development.

Hydro-electric energy and agencies such as the Alberta Utilities Commission and the Surface Rights Board are not included under the REDA. Mineral tenure functions of the Alberta Department of Energy will be phased into the functions of the Regulator. However, at the date of this writing, there is no indication of the timing of such integration.

REDA, supra note 3 , s 2(1)(a). 
authority over "energy resource enactments"101 and the Public Lands Act, ${ }^{102}$ the Environmental Protection and Enhancement Act, ${ }^{103}$ and the Water Act, ${ }^{104}$ insofar as those statues relate to energy resource development.

While parts of the REDA were proclaimed into force on 17 June $2013,{ }^{105}$ implementation will be done in phases. ERCB Bulletin 2013-23 provides that Phase 1 (which occurred on 17 June 2013) will "launch the Regulator and its new governance model," including integration of ERCB functions. ${ }^{106}$ Phase 2 is expected to occur in the Fall of 2013 and will integrate additional ESRD responsibilities, including public land and geophysical jurisdiction and the new landowner agreement registry (discussed below). Finally, Phase 3 is scheduled to be complete by Spring 2014 and will transfer ESRD environmental and water authorization functions to the Regulator as they relate to oil and gas activities. Public consultation is expected to be undertaken by the government in the Spring of 2014 to elicit feedback and identify potential issues before final integration. ${ }^{107}$

The REDA represents a significant change from the regime that has governed upstream energy projects in the province. Depending on the project, that regime required approval and oversight from the ERCB, ESRD and the Alberta Department of Energy, each acting as separate and distinct entities. The REDA is an attempt to alleviate the duplication and complexities that, in the past, have been seen to result in project delay and uncertainty.

While many view a new regulatory regime as laudable, on closer review, a number of the changes lead to more questions and concerns than they answer. In this regard, many of the changes to the Alberta regime echo those that have been made at the federal level and may raise similar questions related to independence and procedural fairness discussed above.

This section addresses certain changes to the provincial regulatory regime, uncertainties in the process, and the issues that the Regulator, project proponents, and other stakeholders may encounter as they engage in the process. We have focused on the following specific and substantive changes that represent significant departures from the current regime:

- $\quad$ the requirement for the Regulator to comply with government policy;

"Energy resource enactment" is defined in section 1(1)(j) of the REDA as the Coal Conservation Act (RSA 2000, c C-17), the Gas Resources Preservation Act (RSA 2000, c G-4), the Oil and Gas Conservation Act (RSA 2000, c O-6), the Oil Sands Conservation Act (RSA 2000, c O-7), the Pipeline Act (RSA 2000, c P-15), the Turner Valley Unit Operations Act (RSA 2000, c T-9), a regulation or rule under any of these enactments or any other enactment prescribed by regulation.

ERCB, “Bulletin 2013-23,” online: Alberta Energy Regulator < http://www.aer.ca/documents/bulletins/ Bulletin-2013-23.pdf $>$. Pursuant to the Bulletin, application and submission processes to the Regulator will continue in a similar manner to how they are dealt with before the ERCB. Under the Responsible Energy Development Act Transition Regulation, Alta Reg 92/2013, proceedings commenced under the Energy Resources Conservation Act, RSA 2000, c E-10 [ERCA], shall be completed in accordance with the REDA, and ERCB members conducting a hearing, inquiry, or other proceeding under the ERCA are deemed to be appointed as hearing commissioners for the purpose of completing that proceeding. online: Alberta Energy <http://www.energy.alberta.ca/Org/pdfs/WWH_REDAconsultations.pdf> [Conversations with Albertans]. 
- $\quad$ time limits for decision-making;

- $\quad$ public participation rights and the requirement (or not) for a hearing; and

- $\quad$ enforcement of voluntarily-registered private surface agreements.

\section{B. DRIVERS FOR CHANGE}

While there has not been a provincial example of regulatory delay and complexity for a major energy project as stark as the MGP or Gateway, described above, it is generally recognized that there is room for improvement in the coordination and consideration of upstream energy projects in Alberta. Although there have been recent attempts to integrate the functions of the various provincial bodies and government agencies involved in the approvals process, ${ }^{108}$ these measures have not answered fundamental concerns about the clarity or efficiency of the process.

In response to growing frustration over the uncertainty in the regulatory process, the provincial government commenced the Regulatory Enhancement Project (REP) in 2010. ${ }^{109}$ As part of the REP, a provincial regulatory task force was formed to create a clear, predictable, and efficient regulatory system to bolster Alberta's competitiveness in the growing international resources market. The task force made six recommendations to the provincial government, including the establishment of a single integrated regulatory body that would have oversight and decision-making powers in respect of upstream energy resource development in the province. ${ }^{110}$

The “one application, one review and one decision" model in the REDA stems from the task force's recommendation and is intended to improve regulatory efficiency and streamline what is, especially for major energy projects, often a complicated process that involves many stages of review and authorization. Whether and how these goals will be borne out in practice is open for debate and is discussed below.

\section{Policy Assurance Function}

One of the effects of the REP was to clarify responsibility over energy development policy in the province, with the government being given responsibility for developing policies and the Regulator being given responsibility for carrying out those policies (the provincial government calls this the "policy assurance" function). This is a substantive shift from the

For example, through joint ERCB/ESRD proceedings for major projects, which were intended to concurrently consider matters under the ERCB's energy mandate and ESRD's environment mandate or through the recent amalgamation of Alberta Environment and Alberta Sustainable Resource Development.

Alberta Energy, “Regulatory Enhancement Project,” online: Alberta Energy <http://www.energy.alberta. ca/initiatives/RegulatoryEnhancement.asp>.

110 The six recommendations made to the provincial government by the task force were to: (1) establish a Policy Management Office (PMO) to set policy direction for the province; (2) establish a single regulatory body; (3) provide a clear public engagement process; (4) develop a systemic and common risk assessment and management approach; (5) adopt a performance management framework and public reporting mechanism; and (6) develop a mechanism to address landowner concerns (Alberta Government, "Responsible Energy Development Act Regulation Development: Public Engagement session," online: Alberta Energy <http://www.energy.alberta.ca/org/pdfs/REDApresentation.pdf>). 
mandate of the ERCB, which was to set and carry out policy for energy development in the province at arm's length from the government, ${ }^{111}$ and has raised the question of whether the Regulator can be a truly independent agency.

The Regulator's policy assurance function is illustrated in three primary ways under the $R E D A{ }^{112}$ First, the REDA affords the designated Minister the power to, by order, (1) set priorities and guidelines for the Regulator to follow in carrying out its powers, duties and functions; and (2) ensure that the work of the Regulator is consistent with the programs, policies, and work of the government regarding energy resource development and public land, environmental, and water management. ${ }^{113}$

Second, in addition to ministerial oversight, the government may also direct the factors that hearing commissioners must consider in reaching a decision on an application, regulatory appeal, reconsideration, or inquiry. ${ }^{114}$ While these factors may be set by regulation under the $R E D A,{ }^{115}$ the $R E D A$ also suggests that such factors may be established outside of the legislative process. ${ }^{116}$ While regulations, unlike legislation, may be implemented or modified by cabinet relatively easily and with little or no notice or debate, this provision provides even broader authority to the provincial government and leaves open the possibility that cabinet may establish different factors for decision making depending on the proposed project. ${ }^{117}$ To this end, the General Regulation allows the Regulator to provide a copy of a statement of concern to the Minister if the statement of concern contains information that is pertinent to policy development. ${ }^{118}$

Third, in accordance with the provincial government's intention that the integrated regulatory system "consider what is healthy for the environment, the economy, and society," 119 the REDA mandates that the Regulator act in accordance with regional plans issued under the Alberta Land Stewardship Act. ${ }^{120}$ This, more than any other change, appears to be specifically directed towards ensuring that the provincial government's focus on land use and cumulative effects management in the province is reflected in regulatory decision

111 For example, under various ERCB Directives.

112 Other aspects of the REDA that fall outside the scope of this article but have raised questions about regulatory independence include the establishment of the roster of hearing commissioners by cabinet for indefinite terms and on remuneration established by the Lieutenant Governor in Council (REDA, supra note 3, s 11) and the ability of the Minister to require the Regulator to disclose information (including confidential and personal information) (ibid, s 16).

$113 \quad$ Ibid, s 67.

$114 \quad$ Ibid, s 15.

115 Factors are prescribed in section 3 of the Responsible Energy Development Act General Regulation, Alta Reg 90/2013,) [General Regulation], and are discussed below.

116 Section 15 of the REDA requires the Regulator to consider factors prescribed by regulations as well as "any other factor it may or must consider in considering the application or conducting the regulatory appeal, reconsideration or inquiry” (REDA, supra note 3).

117 While administrative bodies are not typically bound by precedent, the criteria in place under the ERCB's regime were generally regarded as providing stakeholders with helpful guidance as to whether or not an application would be granted, although such applications were always subject to the ERCB's broader public interest mandate. The Regulator's “policy assurance” function and the government's broad ability to direct the Regulator's decisions in this regard may, contrary to the purpose of the regime changes, put certainty regarding regulatory decision making into question.

General Regulation, supra note 115, s 7.

Conversations with Albertans, supra note 107 at 1.

SA 2009, c A-26.8 [ALSA]. See also REDA, supra note 3, s 20. To date, only the Lower Athabasca Regional Plan (LARP), which pertains to the oil sands area of the Province, has been issued under the ALSA. 
making and that energy projects that otherwise meet legislative requirements, but are contrary to land use and cumulative effects policies, are rejected.

While the REDA is ostensibly not intended to detract from the Regulator's arm's length relationship with the government, the Regulator's policy assurance function raises questions as to whether the Regulator is an independent entity. While certain government policies are likely to have impacts that society as a whole views as generally positive (for example, policies that establish cumulative effects standards under the ALSA), the REDA does not limit government direction to compliance with environmental and socio-economic goals. The outstanding question is how far the government will take the policy assurance function and how that may impact the perceived or actual independence of the Regulator.

While the REDA allows for regulatory appeal, ${ }^{121}$ reconsideration, ${ }^{122}$ and appeal, on leave, to the Alberta Court of Appeal ${ }^{123}$ in certain circumstances, it does not provide an interested party with the ability to seek any form of review of government policy direction to the Regulator or of those rules and regulations that may be put in place to guide the Regulator's decision making. This suggests that it is the provincial government, as opposed to the Regulator or the courts, that could have the final say over energy resource decisions in the province.

Although the provisions of the REDA regarding policy direction to the Regulator are new, it is arguable that the ERCB had been moving towards a "policy assurance" role for a number of years ${ }^{124}$ and had been subject to ongoing criticism that it had exercised its mandate for the benefit of industry. Outside of the legislative provisions discussed above, these criticisms have arisen in the past for many of the same reasons that they do now, including the reason that many of the individual ERCB decision makers had an industry background and because the ERCB had a mandate to ensure the orderly and efficient development of Alberta's resources in the public interest. The provisions of the $R E D A$ may be seen as formalizing what was already considered by some to have been an influential relationship among government, industry, and the ERCB. ${ }^{125}$

\section{TIME LIMITS FOR DECISION-MAKING}

Similar to the changes to the NEB process described above, the REDA also contemplates timelines for decision-making by the Regulator in respect of the hearing of an application, ${ }^{126}$ the hearing of a regulatory appeal, ${ }^{127}$ and reconsideration. ${ }^{128}$ Timelines are not established in

REDA, ibid, ss 36-41.

Ibid, ss 42-44.

Ibid, s 45.

Recently, for example, a bulletin was published which prohibits the ERCB from disposing of an application that does not comply with the LARP (ERCB, "Bulletin 2012-22," online: Alberta Energy Regulator <http://www.aer.ca/documents/bulletins/Bulletin-2012-22.pdf>).

In addition to raising questions of independence, it is also apparent that the changes could have consequences not intended by the government. While the government of the day may view the Regulator's policy assurance function as a useful tool, neither government nor government policy are static. In this regard, a change in government might result in a change in the criteria and policies that guide the Regulator's decision-making.

REDA, supra note 3 , s 35 .

Ibid, s 41.

Ibid, s 44. 
the REDA, but are prescribed in the Rules. ${ }^{129}$ At the time of writing, the only prescribed time periods are: (1) with respect to an application for leave to appeal, it must be made within one month from the date of the decision and must be returnable within two months from the day the application is filed; ${ }^{130}$ and (2) with respect to the issuance of a final written decision posthearing where decisions must be made within 90 days from the date of the conclusion of a hearing, regulatory appeal, or reconsideration. ${ }^{131}$ It is possible that additional requirements could be imposed that establish mechanisms for adherence to timelines and the consequences of a failure of the Regulator to comply with timelines. ${ }^{132}$

The implementation of timelines for decision-making is intended to bolster the government's goals related to regulatory efficiency. It is anticipated that timelines will streamline the review process and provide certainty to project proponents and other stakeholders regarding the timeframe for decision making. This certainty, in turn, is expected to encourage investment in Alberta's natural resources. Unlike the federal regime, however, the REDA gives the Regulator broad discretion to expand prescribed timelines. In particular, section 41 of the Rules allows the Regulator, on its own initiative or motion, to extend or abridge a prescribed time limit on any terms that it considers appropriate. ${ }^{133}$ While increased regulatory efficiency is, therefore, far from certain, the issue of more concern to some is how prescribed timelines might impact regulatory independence and procedural fairness.

Concerns about procedural fairness described above in the context of timelines imposed on NEB decision-making could apply equally to timelines in the provincial process, depending on the scope of existing and future rules and, at the very least, raise a question as to whether or not the Regulator is the master of its own process. A regulatory regime that values expediency over comprehensive and complete decision-making may be exposed to concerns about whether or not the underlying process is fair. As such, it will be important that expediency is balanced with comprehensive and complete decision-making that is proportional to the complexity of the subject before the Regulator.

Alberta Energy Regulator Rules of Practice, Alta Reg 99/2013 [Rules].

General Regulation, supra note 115, s 5.

Rules, supra note 129 , ss $28,33,35$.

While not currently in place, there is a possibility that timelines for other stages of the process (prior to the conclusion of the hearing) could be set by rules and regulations. In such a case, the preliminary onus would likely be on the project proponent to submit a complete application to the Regulator, while the remainder of the process could be largely out of the project proponent's hands. If such timelines are imposed, it is possible that there could come a point in the decision-making process where no further information would be permitted regardless of its relevance to the matter at issue. This would raise questions as to whether and how the Regulator would ensure that the record is complete and that sufficient evidence on which reasons could be provided to support its decision is available.

An issue with respect to timelines is the likelihood that "offramps" from the process will be included in the regime (similar to those discussed above in the context of the NEB) which could result in uncertainty regarding the time frame for decision-making. In accordance with section 41 of the Rules, timelines are not absolute and should be regarded by stakeholders as the minimum time within which a decision will be rendered. 


\section{E. Public Participation}

Under the REDA, the Regulator may provide notice of an application for a proposed project $^{134}$ and any party who believes that he or she is directly and adversely affected by an application may file a statement of concern with the Regulator. ${ }^{135}$ If the Regulator determines that a party may be directly and adversely affected, that party will have standing in the proceeding, and the Regulator will decide whether or not to conduct a public hearing. ${ }^{136}$ These provisions raise a number of questions, including: who will be found to be directly and adversely affected; when might the Regulator exercise its discretion to hold a hearing; and what are a project proponent's stakeholder consultation and notification obligations?

\section{DiRECTLY AND ADVERSELY AFFECTED}

During the public consultation initiative associated with the REDA, public concerns were raised regarding the definition of "directly and adversely affected" in the determination of standing. ${ }^{137}$ While this is the same test that was applied by the ERCB, it is not a generally well-understood concept and many hoped that it would be clarified under the new regime. ${ }^{138}$

While the ERCB had historically favoured an interpretation of the test for standing that considered only the proximity of a party (or its rights) to the proposed development, such an interpretation had been criticized (by the public and the courts) as being overly narrow, especially given that the ERCB's mandate extended to the consideration of social and environmental effects, which are often wider-reaching than the notification and consultation distances prescribed in ERCB directives. ${ }^{139}$

The test for standing before the ERCB has been described as follows:

First is a legal test, and second is a factual one. The legal test asks whether the claim, right or interest being asserted by the person is one known to law. The second branch asks whether the Board has information which shows that the application before the Board may directly and adversely affect those interests or rights. The second test is factual. ${ }^{140}$

REDA, supra note 3, s 31. Section 5 of the Rules, supra note 129 provides that the Regulator may issue notice of an application if it is considering deciding an application without a hearing. Where the Regulator does issue a notice, section 5 of the Rules prescribes certain requirements. This appears to be a more limited notice requirement than contemplated by the government in the REDA consultation process, during which the government suggested that notice would be provided to all Albertans. REDA, ibid, s 32.

REDA, ibid, s 33; Rules, supra note 129, s 7.

Conversations with Albertans, supra note 107 at 5.

ESRD applies a "directly affected" standard in determining who is an interested party. The interpretation of this test and how it may compare to the "directly and adversely affected test" is beyond the scope of this article.

139 See e.g. ERCB, “Directive 023: Guidelines Respecting an Application for a Commercial Crude Bitumen Recovery and Upgrading Project” (September 1991), online: Alberta Energy Regulator < http://www.aer. ca/documents/directives/Directive023.pdf; ERCB, "Directive 056: Energy Development Applications and Schedules” (1 September 2011), online: Alberta Energy Regulator <http://www.aer.ca/documents/ directives/Directive056.pdf> [Directive 056]; ERCB, "Directive 060: Upstream Petroleum Industry Flaring, Incinerating, and Venting” (3 November 2011), online: Alberta Energy Regulator <http://www. aer.ca/documents/directives/DraftDirective060.pdf $>$.

140 Dene Tha' First Nation v. Alberta (Energy and Utilities Board), 2005 ABCA 68, 363 AR 234 at para 10. 
In addition, the courts have confirmed (in support of ERCB practice) that a party who had a right to be consulted under an ERCB directive had an adequate legal interest in the application, but also that "directly and adversely affected" did not mean that a party was required to show that it was affected differently or to a greater degree than the general public. ${ }^{141}$ More broadly, the rationale for standing in an ERCB proceeding has been described as follows:

The right to intervene in the Act is designed to allow those with legitimate concerns to have input into the licencing of oil and gas wells that will have a recognizable impact on their rights, while screening out those who have only a generic interest in resource development (but no "right" that is engaged), and true "busybodies."142

Despite these judicial pronouncements, the ERCB did not take the opportunity to clarify or expand the requirements to show a direct and adverse effect, and the test has not been explained any further under the REDA.

Related to this issue is the question of whether public interest groups that do not have an interest in land or other rights that may be impacted by a project will be granted standing under the new regime. However, the "directly and adversely affected" test had been interpreted by the ERCB much more narrowly than the participation rights in the prior NEB regime discussed above, for example, once a party was found by the ERCB to be directly and adversely affected, the ERCB typically allowed other parties, including public interest groups, to participate in the proceeding. ${ }^{143}$

While the narrowing of hearing rights, discussed below, may suggest reduced rights of participation, it is possible that the broader focus of the government on cumulative effects may give public interest groups a better case for inclusion. Furthermore, if hearings are not automatic, there may be little downside for the Regulator to cast a wider net to include additional parties in the application process.

Finally, the prescribed factors in the General Regulation may also limit standing in a proceeding before the Regulator. ${ }^{144}$ Section 3 of the General Regulation provides that the Regulator is to have regard to the following factors in its consideration of applications, regulatory appeals, reconsiderations or inquiries: (1) the social and economic effects of the energy resource activity; (2) the effects of the energy resource activity on the environment; and (3) the impacts on a landowner ${ }^{145}$ as a result of the use of the land on which the energy resource activity is or will be located.

Kelly v Alberta (Energy Resources Conservation Board), 2009 ABCA 349, 464 AR 315 at paras 24-33. Kelly v Alberta (Energy Resources Conservation Board), 2011 ABCA 325, 344 DLR (4th) 41 at para 26.

Although oftentimes with limited rights of participation.

Supra note 115.

"Landowner" is not defined in the REDA or the General Regulation, and a plain reading of the term suggests that occupants or other interest holders under the PLA may not qualify as "landowners" for the purpose of this provision. Impacts to landowners' private interests could be wide in scope, and this raises the question as to how these interests will be considered by the Regulator relative to the broader public interest. 
Section 15 of the REDA contemplates consideration of these prescribed factors but also allows the Regulator to take into account "any other factor it may or must consider in considering the application or conducting the regulatory appeal, reconsideration or inquiry." "146 Furthermore, although the public interest (the focus of the ERCB's mandate under section 3 of the ERCA) is not included in the list of prescribed factors and has been removed from the $R E D A$, certain energy resource enactments continue to direct consideration of the public interest. ${ }^{147}$ Because the mandate of the Regulator extends to carrying out energy resource enactments, ${ }^{148}$ the public interest will continue to be a relevant consideration for certain projects. Therefore, while section 3 of the General Regulation suggests that the only parties who may have standing are those who may be directly and adversely affected in a manner that touches on the prescribed factors, when read in the context of the REDA regime as a whole, it is apparent that the Regulator's jurisdiction is not so strictly limited. The Regulator does, however, have broad discretion in this regard, and it remains to be seen how widely rights of participation will be extended.

\section{RIGHT TO A HEARING UNDER THE REDA}

While the regulatory scheme under the REDA has been touted by the government as being more inclusive for interested parties than either the ERCB or ESRD regimes, there are concerns that the rights of directly and adversely affected parties to a hearing ${ }^{149}$ have been removed or limited by the $R E D A .{ }^{150}$

The REDA allows the Regulator to make a decision with or without a hearing, but provides that a hearing must be conducted in prescribed circumstances, including where a hearing is required pursuant to an "energy resource enactment," under the Rules and under circumstances prescribed by the regulations. ${ }^{151}$ Section 7 of the Rules provides further guidance, stating that the Regulator may convene a hearing if it is required under an energy resource enactment or the regulations, or if a statement of concern was filed within the prescribed time period. ${ }^{152}$ The Rules clarify, however, that a hearing is not required if the person filing the statement of concern has not demonstrated a potential direct and adverse effect, if the statement of concern is frivolous, vexatious or without merit, or if the objection raised has been addressed. ${ }^{153}$

Notably, and unlike the regime that governed the ERCB described below, a hearing before the Regulator is not expressly mandatory where a directly and adversely affected party has outstanding concerns. While a potential direct and adverse effect may trigger a hearing, the Regulator has significant discretion to determine that a hearing is not appropriate even if a potential direct and adverse effect is shown. For example, it is within the Regulator's jurisdiction to find that a statement of concern filed by a potentially directly and adversely For example, section 4 of the Pipeline Act (supra note 101), section 4 of the Oil and Gas Conservation
Act (supra note 101) and section 3 of the Oil Sands Conservation Act (supra note 101).

REDA, supra note 3 , s 2.

The Rules reference oral, written and electronic hearings (supra note 129, s 1).

Conversations with Albertans, supra note 107 at 5.

REDA, supra note 3 , s 34.

Rules, supra note 129.

Ibid. 
affected party is without merit or that the concern has been addressed. Under the ERCB's regime, questions of merit and satisfaction of concerns are typically the subjects of the hearing itself and not preliminary issues to be determined outside of the hearing process. This raises questions as to the grounds and process the Regulator might rely on to deny a hearing and the rights of interested parties to seek a review or appeal of those decisions.

Furthermore, even if standing is granted to a party, the REDA does not link standing to a hearing. Under the ERCA, the ERCB was required to give parties who may be directly and adversely affected by a decision on an application the right to participate in a proceeding, including an opportunity to furnish evidence, conduct cross-examination, and make argument. ${ }^{154}$ The paramountcy of a right to a hearing in the context of a proceeding before the ERCB was articulated by the Alberta Court of Appeal in Kelly v. Alberta (Energy Resources Conservation Board), ${ }^{155}$ wherein the Court held that "it is accepted that citizens have a right to provide input on public decisions that will affect their rights”"156 and that "[g]ranting standing and holding hearings is an important part of the process that leads to the development of Alberta's resources. The openness, inclusiveness, accessibility, and effectiveness of the hearing process is an end unto itself."157

While the ERCA required that the ERCB convene a hearing if parties who may have been directly and adversely affected by a decision on an application had outstanding concerns, subject to the Regulator's discretion in the Rules, the REDA only requires a party who may be directly and adversely affected to be heard if the Regulator first makes the decision to conduct a hearing. ${ }^{158}$ This is reflected in section 7 of the Rules, which provides that the Regulator may convene a hearing if the conditions described above are met. ${ }^{159}$

The process contemplated under the REDA appears to more closely reflect the process that is currently used by ESRD to decide environmental applications under the EPEA. ${ }^{160}$ Under the EPEA process, on the initial application there are typically very limited rights of participation, but participatory rights expand if an appeal of the decision on that application is made to the Environmental Appeals Board. ${ }^{161}$ This is unlike the ERCB process which had relatively wide initial rights of participation, but limited rights to an appeal. While creating a hybrid of the ERCB and EPEA processes makes some sense if the processes are to be integrated, it is arguable that the REDA combines the narrowest elements of both worlds limited rights to both a hearing and an appeal. Furthermore, while the EPEA process has not been found to be procedurally unfair, it may be difficult to justify removing rights through the REDA that were afforded by the ERCB given that the nature of the projects proposed will not change.

This is similar to the regulatory process in other jurisdictions, such as in British Columbia before the British Columbia Oil and Gas Commission.

Appeals to the Environmental Appeals Board will not be available for energy resource applications. 
In addition to narrowing the right to a hearing established under the ERCA and at common law, there is also a question as to whether the Regulator will be bound by the Administrative Procedures and Jurisdiction Act, ${ }^{162}$ which establishes procedural obligations of designated administrative tribunals. ${ }^{163}$ Among other things, the APJA requires designated tribunals to provide notice of applications ${ }^{164}$ to parties "whose rights will be varied or affected by the exercise of a statutory power or by an act or thing done pursuant to that power"165 and to provide an opportunity to those parties to give evidence and make representations ${ }^{166}$ and possibly conduct cross-examination. ${ }^{167}$

The REDA makes no reference to the APJA and the Regulator is not a designated tribunal under the APJA. ${ }^{168}$ Given that many of the obligations under the APJA appear to conflict with the narrow rights of participation established under section 34 of the REDA, it appears unlikely that the APJA will be amended to add the Regulator.

The REDA seemingly closes the door on what many, including the courts, viewed to be compulsory rights of participation for directly and adversely affected parties through the hearing process. While the government's stated intention is to create more opportunities for public participation, depending on how the Regulator applies its discretion with respect to hearings, it is debatable whether or not this will in fact be the case. ${ }^{169}$

\section{STAKEHOLDER CONSULTATION AND NOTIFICATION REQUIREMENTS}

An aspect of the application process under REDA that is not addressed in the Act and is not yet the subject of detailed rules or regulations is the stakeholder consultation and notification requirements that must be met by a project proponent prior to filing an application. ${ }^{170}$

The stakeholder consultation and notification process under the former regime provides a good example of the complexities in the upstream approval process that the REDA attempts

RSA 2000, с A-3 [APJA].

While APJA obligations mirror the rights under the ERCA (that is, there is no guarantee in either to an oral hearing or to cross-examination), it was often the practice of the ERCB to convene an oral hearing and allow cross-examination where potentially directly and adversely affected parties have outstanding objections.

APJA, supra note 162 , s 3.

Ibid, s 1(b).

Ibid, s 4.

Ibid, s 5 .

The ERCB has been removed as a designated tribunal under the APJA. The Regulator is, however, specifically designated under the Designation of Constitutional Decision Makers Regulation, Alta Reg 69/2006.

Division 2 of the Rules, supra note 129 establishes a new "participant" cost regime under which "participant" is defined as "a person or group or association of persons who have been permitted to participate in a hearing for which notice of hearing is issued, but unless otherwise authorized by the Regulator, does not include a person or group or association of persons whose business includes the trading in or transportation or recovery of any energy resource.” While a detailed analysis is outside the scope of this article, the new cost regime appears to cast a wider net than the former ERCB cost regime (applicable to "local interveners" who had interests in or actual occupation of lands that may have been directly and adversely affected by a project (ERCA, supra note 106, s 28)), which could have a significant impact on stakeholder eligibility for costs. This will be especially true when a hearing is convened, however, even when a hearing is not convened, a participant may be eligible for costs so long as a notice of hearing has been issued (the new cost regime provides that costs will not be awarded when an application is withdrawn before a notice of hearing is issued).

The Rules, supra note 129 address application requirements to a limited extent in section 3. 
to address. These requirements varied depending on the nature, size, and scope of activity proposed and the authorization required, and were set by legislation, policies, and directives, depending on the circumstances. To this end, the ERCB and ESRD did not necessarily impose the same requirements and it was up to the project proponent to understand and meet all obligations. Whether final consultation and notification rules and regulations will ultimately reflect these requirements or establish new obligations is unknown. ${ }^{171}$

Prior to filing an upstream energy development application, project proponents were commonly required to engage with landowners (Crown or freehold owners), licence or permit holders under the PLA, occupants of freehold surface lands, sub-surface interest holders, facility licencees, the general public, and First Nations. While the government has not provided any indication as to whether and how stakeholder consultation and notification obligations may change under the REDA, there has been no direct suggestion that the relevant parties will change. ${ }^{172}$

For example, while the REDA expressly provides that the Regulator has no jurisdiction to assess the adequacy of Crown consultation with First Nations, ${ }^{173}$ there has been no indication that project proponents will not be required to engage with First Nations as part of their public participation program. Every indication is that applicants must continue to coordinate with the provincial government to determine which, if any, First Nations may be impacted by the application. The Regulator is also expected to continue to hear from First Nations where it is shown that they may be directly and adversely impacted by a decision on the application. The following reasoning of the ERCB is likely to continue to apply:

The ERCB application process places broad consultation obligations upon project proponents which ensure that First Nations can learn about projects and participate in the Board's process. Both the application and hearing process provide an opportunity for the Board to hear from First Nations regarding potential effects of projects upon them and allow the Board to assess those effects. In this way, the Board's own process is just one component of a much broader consultation process and will provide the Crown with an opportunity to determine what, if any, further consultation and accommodation is required. ${ }^{174}$

\section{F. Enforcement of Private Surface Agreements}

One of the issues identified by the REP regulatory task force was to address landowner concerns regarding the absence of an efficient and effective mechanism to hold an operator

Detailed ERCB application requirements were set by directives, for example, Directive 056, supra note 139. Although Directive 056 is not specifically referenced in the REDA regime, it is likely to continue to apply unless or until otherwise ordered as it is incorporated by reference into the regulations for certain energy resource enactments which fall under the Regulator's mandate and have not yet been amended.

172 Note, however, the above comments related to section 3 of the Rules, supra note 129 that occupants or other interest holders may not qualify as "landowners."

173 REDA, supra note $3, \mathrm{~s} 21$. While this is an important change that appears to codify the practice of the ERCB (see letter from ERCB to Garry Appelt, Don G Davies \& Douglas B Titosky (24 August 2012), online: Ablawg <http://www.ablawg.ca/wp-content/uploads/2012/09/Application-1636580-ERCB-Rea sons-NQCL.pdf $>$ [Letter]), further discussion of this change, and pending provincial guidance regarding First Nations consultation is outside of the scope of this article. Letter, ibid at 8. 
accountable if it failed to meet its obligations under private surface land agreements. ${ }^{175}$ Although the task force recommended that the "Surface Rights Board or another body" be given jurisdiction to resolve such disputes, it is the Regulator under the REDA that has this role. ${ }^{176}$

Once registered with the Regulator, a private surface agreement can be enforced against the holder of the agreement (that is, the operator) by order of the Regulator if it is determined that the holder is not in compliance with that agreement. ${ }^{177}$ Private surface agreement enforcement rights relate only to agreements made after coming into force of the relevant provisions. ${ }^{178}$ Therefore, these provisions will have no impact on agreements that pre-date the proclamation of these sections of the REDA.

Under the current regime, landowners or occupants must go to court, or in some cases, to the Surface Rights Board (SRB), ${ }^{179}$ if they believe an operator is in violation of a surface agreement. By giving the Regulator the jurisdiction to enforce such agreements, landowners and occupants are expected to have a more efficient and practical mechanism by which to protect their rights.

While extending the powers of the Regulator to the enforcement of private surface agreements is, on its face, a step towards addressing landowner concerns that are often associated with energy development in the province, numerous questions arise that must be answered before it can be determined whether the Regulator's enforcement jurisdiction is a positive step forward. In this regard, public consultation revealed scepticism about the enforcement mechanisms and suggested that many landowners would rather bring their claims in court. ${ }^{180}$

A number of the concerns and questions raised by the enforcement provisions of the $R E D A$ are discussed below.

\section{SCOPE OF "Private Surface AgreemenT"}

The definition of "private surface agreement" in the REDA refers only to an agreement as defined in the rules. ${ }^{181}$ What that definition will include is not yet clear.

There are numerous types of private agreements negotiated between a landowner or occupant and an operator for surface access. These may include agreements that relate only

Government of Alberta, Enhancing Assurance: Report and Recommendations of the Regulatory Enhancement Task Force to the Minister of Energy (December 2010), online: Alberta Energy <http:// www.energy.alberta.ca/org/pdfs/FinalEnhancingAssuranceReportREP.pdf $>$ at 19.

Part 3 of the REDA, supra note 3, which establishes requirements for the enforcement of private surface agreements, has not come into force. Bulletin 2013-23, supra note 106, suggests that Part 3 is likely to be implemented during Phase 2 of integration implementation (Fall 2013).

REDA, supra note 3 , s 64 .

Ibid, s 62(2).

For example, under section 36 of the Surface Rights Act, RSA 2000, c S-24 [SRA], upon receipt of evidence of non-payment by an operator under a compensation order or surface lease, the SRB may order that the operator pay outstanding amounts or, failing that, suspend or terminate the operator's right to enter the lands.

Conversations with Albertans, supra note 107 at 6.

REDA, supra note 3, s 62(1)(e). 
to access and compensation, commonly called right of way agreements, easements, or surface leases. It is also common for parties to enter into commitment letters or "cooperation agreements" in parallel with surface access agreements which establish broader landowner or occupant obligations of cooperation with the operator and often include sensitive information regarding commercial and compensation matters that are subject to strict confidentiality provisions.

If the definition of "private surface agreement” includes, or could be interpreted to include commitment letters or cooperation agreements, it could discourage parties from making such commitments or entering into such agreements, as the perceived pitfalls of disclosure of the terms of such letters or agreements ${ }^{182}$ (or even their existence) could be seen in some circumstances to outweigh the benefits, such as regulatory expediency, that might be derived from those agreements.

\section{RIGHTS DO NOT EXTEND TO OPERATORS}

The rights of operators in respect of the enforcement of private surface agreements are limited (and potentially non-existent) under the REDA. First, not only does the REDA not allow an operator to register a private surface agreement, but it also does not allow an operator to complain to the Regulator in the event of a breach by a landowner or occupant. Furthermore, the REDA does not address whether an operator may make submissions to the Regulator as to the conduct of the landowner or occupant in the event that a landowner or occupant seeks to have its rights under the agreement enforced by the Regulator.

While the goal of the provisions (to ensure that obligations under private agreements are fulfilled) should theoretically apply equally to operators and landowners and occupants, this imbalance presumably arises because the Regulator has broad authority over operators, but limited authority over individuals. While it may be within the Regulator's jurisdiction to require an operator to comply with a surface land agreement, that jurisdiction is unlikely to extend in the same way to individual landowners or occupants.

\section{PublicAtion OF Registered AgREEMENTS}

While the REDA overrides confidentiality provisions that may be included in private surface agreements, ${ }^{183}$ it does not expressly require that agreements be registered or made available publicly.

The publication of private agreements would be of concern not only to operators, but also to landowners and occupants who might not want the specific terms of an agreement (especially regarding compensation) disclosed. Public consultation results suggest that if registered agreements are made publicly available, it could undermine the willingness of landowners and occupants to register those agreements. ${ }^{184}$ It remains to be seen whether the Regulator will require that the agreements be made public and, if so, whether the Regulator 
will permit the landowner or occupant or the operator to redact the document to protect sensitive information.

\section{APPEAL FROM ENFORCEMENT DECISION}

While a regulatory appeal is available for prescribed decisions made by the Regulator without a hearing in the context of an "energy resource enactment," the EPEA, ${ }^{185}$ the Water Act ${ }^{186}$ the $P L A,{ }^{187}$ and the regulations, ${ }^{188}$ it may not apply to enforcement orders made by the Regulator in respect of private surface agreements. This, especially when coupled with what may be limited rights of an operator to participate in an enforcement proceeding, raises the question of whether the enforcement regime is procedurally fair.

Although a regulatory appeal from an enforcement decision may not be available, the Regulator may, in its discretion, reconsider and confirm, vary, suspend, or revoke a decision made by it ${ }^{189}$ which may provide some safeguard in the event that an operator (or landowner or occupant) has concerns about a decision of the Regulator regarding the enforcement of a private surface agreement.

\section{Alternative Dispute Resolution}

The REDA allows the Regulator to use alternative dispute resolution (ADR) when it considers it appropriate to do so. ${ }^{190}$ While the REDA provides that terms and conditions of registered private surface agreements are overridden by Part 3 of the $R E D A$, which pertains to the enforcement of those agreements, there is a question as to whether the Regulator could require parties to a registered agreement to participate in ADR even if that is not contemplated under, or is in conflict, with the terms of that agreement. This raises the broader issue of parties to private agreements not truly knowing what they are bargaining for.

\section{IMPACTS ON SURFACE RIGHTS BOARD JURISDICTION}

It is unclear from the REDA how far the Regulator may go in enforcing a private surface agreement and how that jurisdiction may overlap or infringe upon the jurisdiction of the SRB.

For example, under the $S R A,{ }^{191}$ the SRB has the jurisdiction to order that an operator pay damages to a landowner or occupant where an operator's activities have resulted in damage to land, livestock, or personal property ${ }^{192}$ and to assess ongoing and recurring losses to the landowner or occupant under the SRA. ${ }^{193}$ It is not clear whether the same or similar powers 
are afforded to the Regulator under the REDA and, if they are, what decision making process will be applied (for example, whether a hearing would be convened).

Given that the SRB is recognized as an expert tribunal regarding matters related to compensation for entry to land (and the Regulator is not), it is unlikely that rights under the REDA would be read to usurp the role of the SRB. However, given the breadth of the provisions, it is conceivable that parties might attempt to use the Regulator's enforcement process to avoid the SRB process. ${ }^{194}$

\section{Conclusion}

Changes to regulatory regimes at both the federal and provincial levels reflect a fundamental transformation in the way that energy resource projects will be considered and approved. Both the federal and Alberta governments have recognized the impact that regulation of major resource development projects can have on economic development. To this end, those governments see value in transitioning regulatory decision-making away from the regulators to governments that set national and provincial policy.

The changes discussed in this article were made to support a streamlined regulatory process that encourages responsible resource development. Questions remain, however, as to whether the new federal and provincial regimes have sufficient safeguards in place to protect stakeholder interests. Changes that erode regulatory independence and that appear to value efficiency of regulatory decision making over procedural fairness may result in challenges not only to resulting decisions, but to the underlying legislation.

In the meantime (and after inevitable short-term growing pains), the federal and provincial changes are likely to have the intended results. The changes will presumably streamline the application process, reduce duplication, and increase regulatory certainty, resulting in faster review and decision-making. Whether or not these efficiencies come at the potential loss of protections typically afforded by the administrative process remains to be seen. or the SRB would reconsider matters that were effectively decided by the Regulator under these provisions of the REDA. 